\title{
THE WELFARE LEVEL OF THE HOUSEHOLDS OF MINAPADI FARMERS IN EPEESI VILLAGE, BASALA SUB-DISTRICT, SOUTH KONAWE DISTRICT
}

\author{
Hasbi Akmal ${ }^{1)}$, Muhammad Aswar Limi ${ }^{\left.{ }^{*}\right)}$, Samsul Alam Fyka ${ }^{1)}$ \\ ${ }^{1}$ Department of Agribusiness Faculty of Agriculture, Halu Oleo University Kendari 93232 Indonesia
}

${ }^{*}$ Corresponding author : aswar_agribusiness@yahoo.com

To cite this article:

Akmal, H., Limi, M., \& Fyka, S. (2020). The Welfare Level of the Households of Minapadi Farmers in Epeesi Village, Basala Sub-District, South Konawe District. JIA (Jurnal IImiah Agribisnis) : Jurnal Agribisnis dan IImu Sosial Ekonomi Pertanian, 5(6), 222 - 228. doi:http://dx.doi.org/10.37149/jia.v5i6.13458

Received: August 10, 2020; Accepted: August 27, 2020; Published: December 31, 2020

\begin{abstract}
This research was motivated by the number of farmers who work on minapadi system (paddyfish integration farming system) in Epeesi Village, Basala Sub-District, South Konawe District in which the welfare level of the minapadi farmers community in the village is not yet known. The purpose of this study was to determine the welfare level of minapadi farmers in the region. The determination of the research area was carried out purposively with the consideration that the village was one of the villages that developed minapadi system in South Konawe District. This research was done in January-February 2020. The number of respondents was 36 households working on minapadi farming system. Data analysis was performed using the indicators from BKKBN and quantitative descriptive analysis technique with cross tables and percentage analysis. The results showed that the average minapadi farmers in Epeesi Village were in KS I with a percentage of $41.67 \%$, so that the welfare level of minapadi farmers in Epeesi Village was still classified low. This is because the community of minapadi farmers has not met all indicators set by BKKBN namely basic needs, psychological needs, development needs, and self-esteem.
\end{abstract}

Keywords: farmers; household; income; minapadi; welfare

\section{INTRODUCTION}

Social welfare is a condition where the material, spiritual and social needs of the citizens are fulfilled in order to live properly and be able to develop themselves so that they can carry out their social functions (Undang-Undang Republik Indonesia Nomor 11 Tahun 2009). The inability of the community to fulfill their daily needs is a problem faced by many countries in realizing the welfare of their people. The high rate of poverty becomes a limitation in the ability to meet the life needs (Sudiharta \& Sutrisna, 2014).

The fulfillment of needs is limited by the household income, especially for those with low income. The higher the household income, the less the income percentage for food will be. In other words, if there is an increase in income and the increase does not change the consumption pattern, the household will be prosperous. Conversely, if an increase in household income can change the consumption patterns, the household will not be prosperous (Sari, Haryono, \& Rosanti, 2014).

Data on the welfare of Southeast Sulawesi Province according to Indonesia Statistics (BPS) can be seen from the indicators of educational level, population, health, family planning and housing fertility, and social conditions. The percentage of households receiving prosperous family card (KKS) can be used as a reference in determining the percentage of prosperous households in Southeast Sulawesi Province, in which it was recorded that $10.67 \%$ of Southeast Sulawesi households are classified as not prosperous. In another case in South Konawe District, there were $12.97 \%$ of households classified as not prosperous (BPS, 2019).

Epeesi Village is one of the villages that has developed Minapadi system in South Konawe District. It was recorded that 68 households in Epeesi Village have increased their economic income through the production of this cultivation system (Ningrum, Limi, \& Fyka, 2019). Minapadi farming activities in Epeesi Village, Basala Sub-District, South Konawe District was started from the farmers' 
own initiative since 2009 with 25 farmers which increased to 68 farmers in 2019. With the development of this Minapadi system, it will have an impact on the absorption of local labor and other business units that emerge as an effort to support the sustainability of this cultivation system. Therefore, through the Minapadi farming, it will increase the household income of Minapadi farmers (Ningrum et al., 2019).

The advantages of Minapadi system include being able to provide rice and protein in the form of fish. Minapadi agribusiness can increase the net income of IDR 7,165,250 (35.29\%), with an R/C ratio of 2.97 and $B / C$ ratio of 1.97 , indicating that this cultivation system is feasible to be developed (Sularno \& Jauhari, 2014). The most important thing from welfare is income, because several aspects of household welfare depend on the level of income. Fulfilling the needs is limited by household income, especially for those with low income. The higher the household income, the less the income percentage for food will be. In other words, if there is an increase in income and the increase does not change the consumption pattern, the household will be prosperous. Conversely, if an increase in household income can change the consumption patterns, the household will not be prosperous (Sari et al., 2014). Therefore, the purpose of this research was to determine the level of household welfare of Minapadi farmers in Epeesi Village, Basala District, South Konawe District. Research on this welfare level has been carried out by (Wardie, 2015) on the contribution of income from local rice farming by $93.05 \%$, in which the amount of contribution illustrates that the source of household income for farmers is dominated by the local rice farming activities of tidal field, the welfare level of farmer households was categorized as not prosperous, described with the proportion of food consumption of $83.48 \%$ and $83.05 \%$.

\section{MATERIALS AND METHOD}

This research was conducted in Epeesi Village, Basala Sub-District, South Konawe District in January-February 2020, which was chosen purposively. The research population was the whole object of the research (Masyhuri \& Zainuddin, 2011). The population in this study were all Minapadi farmer households in Epeesi Village, Basala Sub-district, South Konawe District, amounting to 36 households. This study used quantitative descriptive analysis techniques with cross tables and percentage analysis to explain the welfare level percentage $(\%)=($ Part/Overall) $X(100 \%)($ camelta, 2013). The welfare indicators in this study used indicators from the BKKBN, namely basic needs, psychological needs, developmental needs (developmental needs) and self-esteem.

\section{RESULTS AND DISCUSSION}

\section{The Characteristics of Respondents}

The characteristics of farmers in this study included age, educational level and number of family dependents.

Tabel 1. Characteristics of respondents

\begin{tabular}{lcc}
\hline \multicolumn{1}{c}{ Deskripsi } & Value & Percentage \\
\hline Age & 32 & 0,89 \\
15-55 & 4 & 0,11 \\
$>55$ & 7 & \\
Level of education & 19 & 0,19 \\
Not completed in primary school & 8 & 0,53 \\
Primary school & 2 & 0,22 \\
Junior High school & & 0,06 \\
High school & 15 & 0,42 \\
\hline Number of family dependents & 21 & 0,58 \\
1-2 & &
\end{tabular}

Source: Primary data processed, 2020

Age has an influence on the respondent's physical ability in managing a business. The older the respondent's age will cause the respondent's physical ability to decrease. A person's physical strength in carrying out an activity is closely related to age because when a person's age has passed the productive period, his physical strength will decrease so that his productivity decreases (Dewi \& 
Dewi, 2018). The characteristics of the age of the family heads in Epeesi Village, Basala Sub-District, South Konawe District have a productive age ranging from 15-64 years old.

Higher educated people have more knowledge to improve the performance of that person (Mahendra \& Woyanti, 2014). Education is very important to improve the quality of human resources, in which the higher the educational level, the more abilities and skills they have so they can manage their business more properly. Through education, it is expected that it can change the mindset of the workforce into a professional workforce so that its utilization can be optimal (Dewi \& Dewi, 2018). The characteristics of Educational Level of Minapadi farmers in Epeesi Village, Basala Sub-District, South Konawe District were varied. The educational level of the Minapadi respondents in this study showed that the majority was elementary school graduates.

The number of dependents in the family is the amount in which the family supports the necessities of life. The greater the number of family dependents will also affect a portion of the income in the family. If there are more dependents, the allocation of funds for each child will decrease if it is not accompanied by sufficient income (Purwanto \& Taftazani, 2018). The average number of dependents in Minapadi farmer's household was 3-4 people. This will affect the farmer's expenditure. The number of family dependents greatly affects the income received by the head of the family. The more dependents in the family, the higher income should be obtained by the head of the family so that all household needs can be met.

\section{Indicator of Welfare Level of Minapadi Farmers in Epeesi Village, Basala Sub-District, South Konawe District}

BKKBN divides the level of family welfare into several stages and indicators, namely basic needs, psychological needs, developmental needs and self-esteem.

\section{Basic Needs}

Basic needs is the first indicator set by BKKBN to determine the welfare level. This indicator is used as a requirement for the fulfillment of the prosperous family stage and if one of the points of this indicator is not fulfilled, then it becomes a pre-prosperous family.

Table 2. Fulfillment of basic needs of Minapadi farmers in Epeesi Village

\begin{tabular}{lcc}
\multicolumn{1}{c}{ Indicators } & Respondents & Percentage \\
\hline In general, family members eat two or more meals a day. & 36 & 100 \\
Fulfilled & 0 & 0 \\
Is not fulfilled & 36 & 100 \\
\hline Family members have different clothes for home, work/school and & 0 & 0 \\
traveling. & & \\
Fulfilled & 35 & 97 \\
Is not fulfilled & 1 & 13 \\
\hline The house occupied by the family has a good roof, floor and walls. & & 100 \\
Fulfilled & 36 & 0 \\
Is not fulfilled & 0 & \\
\hline If a family member is sick, he is taken to a healthcare facility. & & 94 \\
Fulfilled & 34 & 6 \\
Is not fulfilled & 2 & 72 \\
\hline If a childbearing-age couple wants to do family planning, they go to & \\
a contraceptive service facility. & & 28 \\
Fulfilled & 26 & \\
Is not fulfilled & 10 & \\
\hline All children aged 7-15 yearsold in the family attend school. & & \\
Fulfilled & & \\
Is not fulfilled & & \\
\hline
\end{tabular}

Source: Primary data processed, 2020

Table 2 shows that there were still many children aged 7-15 years old who did not attend school and very few children over 15 years old have ever attended school. This shows that the people of Epeesi Village do not get a good education so that community performance is less optimal. The higher a person's educational level, the more also their productivity level or workforce performance. In general, people who have higher formal and informal education will have broader insights. People with higher education have more knowledge to improve their performance (Mahendra \& Woyanti, 
2014). From the table, it can also be seen that there were still people who did not use contraceptive services so that the population growth rate of Epeesi Village becomes uncontrolled. This will have an effect on the increasing number of family dependents, thus affecting the income. The greater the number of family dependents will affect a portion of the income in the family and will affect the welfare of the household (Dewi \& Dewi, 2018).

\section{Psychological Needs}

Psychological Needs is the second indicator from BKKBN to determine the welfare level. This indicator is used as a requirement for the fulfillment of the second prosperous family stage.

Table 3. The fulfillment of psychological needs of Minapadi farmers in Epeesi Village

\begin{tabular}{|c|c|c|}
\hline Indicators & Respondents & Percentage \\
\hline $\begin{array}{l}\text { In general, family members perform worship according to their } \\
\text { respective religions and beliefs. } \\
\text { Fulfilled } \\
\text { Is not fulfilled }\end{array}$ & $\begin{array}{c}36 \\
0\end{array}$ & $\begin{array}{c}100 \\
0\end{array}$ \\
\hline $\begin{array}{l}\text { At least once a week all family members eat meat/fish/eggs. } \\
\text { Fulfilled } \\
\text { Is not fulfilled }\end{array}$ & $\begin{array}{c}36 \\
0\end{array}$ & $\begin{array}{c}100 \\
0\end{array}$ \\
\hline $\begin{array}{l}\text { All family members receive at least one new set of clothes a year. } \\
\text { Fulfilled } \\
\text { Is not fulfilled }\end{array}$ & $\begin{array}{c}36 \\
0\end{array}$ & $\begin{array}{c}100 \\
0\end{array}$ \\
\hline $\begin{array}{l}\text { The floor area of the house is at least } 8 \mathrm{~m}^{2} \text { for each occupant of the } \\
\text { house. } \\
\text { Fulfilled } \\
\text { Is not fulfilled }\end{array}$ & $\begin{array}{c}36 \\
0 \\
\end{array}$ & $\begin{array}{c}100 \\
0\end{array}$ \\
\hline $\begin{array}{l}\text { In the last three months, the family has been in good health so that } \\
\text { they can carry out their respective duties/functions. } \\
\text { Fulfilled } \\
\text { Is not fulfilled }\end{array}$ & $\begin{array}{c}36 \\
0 \\
\end{array}$ & $\begin{array}{c}100 \\
0\end{array}$ \\
\hline $\begin{array}{l}\text { There is one or more family members who work to earn income. } \\
\text { Fulfilled } \\
\text { Is not fulfilled }\end{array}$ & $\begin{array}{l}11 \\
25\end{array}$ & $\begin{array}{l}31 \\
69\end{array}$ \\
\hline $\begin{array}{l}\text { All family members aged } 10 \text { - } 60 \text { years old can read Latin script. } \\
\text { Fulfilled } \\
\text { Is not fulfilled }\end{array}$ & $\begin{array}{c}30 \\
6\end{array}$ & $\begin{array}{l}83 \\
17\end{array}$ \\
\hline $\begin{array}{l}\text { Couples of childbearing age with two or more children use } \\
\text { contraceptives/drugs. } \\
\text { Fulfilled } \\
\text { Is not fulfilled }\end{array}$ & $\begin{array}{c}33 \\
3\end{array}$ & $\begin{array}{c}92 \\
8\end{array}$ \\
\hline
\end{tabular}

Source: Primary data processed, 2020

Table 3 shows the number of people of in childbearing-age who cannot read and write Latin and do not use contraceptives. This is still closely related to basic needs in table 2 . which affects the level of farmers' knowledge and limitations in accessing written information which will make it more difficult for farmers to develop their farming skills. Those with higher education are more easily motivated to master and apply the technology introduced which in turn will increase the production efficiency (Mahendra \& Woyanti, 2014). The number of dependents in the family becomes uncontrollable because the couples of childbearing-age did not participate in the family planning program. The failure to fulfill the indicators of psychological needs is a benchmark for not fulfilling the requirements to become a prosperous family II for some Minapadi farmers.

\section{Develomental Needs}

Developmental Needs is the $3^{\text {rd }}$ indicator from BKKBN to determine the welfare level. This indicator is used as a requirement for the fulfillment of the prosperous family stage III. 
Table 4. Fulfillment of developmental needs of Minapadi farmers in Epeesi Village

\begin{tabular}{lcc}
\multicolumn{1}{c}{ Indicators } & Respondents & Percentage \\
\hline Families seek to increase religious knowledge. & 36 & 100 \\
Fulfilled & 0 & 0 \\
Is not fulfilled & 36 & 100 \\
\hline Part of the family income is saved in cash or in goods. & 0 & 0 \\
Fulfilled & & \\
Is not fulfilled & 36 & 100 \\
\hline The family has habit of eating together at least once a week used to & 0 & 0 \\
communicate. & 0 & 100 \\
$\quad$ Fulfilled & 36 & 0 \\
Is not fulfilled & 0 & \\
\hline Families participate in community activities in the neighborhood. & & 100 \\
Fulfilled & & 0 \\
Is not fulfilled & 36 & 0 \\
\hline Families get information from newspapers/magazines/radio/tv/ & & \\
internet. & & \\
Fulfilled & &
\end{tabular}

Source: Primary data processed, 2020

The results showed that all requirements to become a prosperous family III were fulfilled by minapadi farmers, but some minapadi farmers could not be categorized as a prosperous family stage III, because the indicators of basic needs and psychological needs were not fulfilled. This shows that the people of Epeesi Village were very concerned about social and religion in their lives which can be seen from the habit of family eating together, and trying to increase religious knowledge through television and other media. Humans are motivated by a number of basic needs which are the same for all species, do not change, and come from a genetic or instinctive source. Needs are also psychological, not purely physiological because, this need is the core of human nature (Muazaroh \& Subaidi, 2019).

\section{Self-Esteem Need}

Self-Esteem is the $4^{\text {th }}$ indicator from the BKKBN to determine the welfare level. This indicator is used as a requirement for the fulfillment of prosperous family stage III plus (KS III +).

Table 5. Fulfillment of self-esteem needs of Minapadi farmers in Epeesi Village

\begin{tabular}{lcc}
\multicolumn{1}{c}{ Indicators } & Respondents & Percentage \\
\hline Make material donations for social activities. & 6 & 17 \\
$\quad$ Fulfilled & 30 & 83 \\
Is not fulfilled & & \\
\hline There are family members who are active as the administrators of & & 3 \\
social associations/foundations/community institutions & 1 & 97 \\
Fulfilled & 35 & \\
Is not fulfilled &
\end{tabular}

Source: Primary data processed, 2020

Table 5 shows the number of Minapadi farmer households that did not provide material contributions to social activities and the Minapadi farmers who were not interested in being active as an administrator of associations or community organizations. This is because Minapadi farmer community has not been able to set aside some of their income for donations to social activities but only to meet their daily needs. It is different with lowland rice farmers since most of their income has met their basic needs, even more so that they are able to make material contributions so that minapadi and lowland rice farmers who are in KS III + are very few. The need for self-esteem is the highest peak of human achievement (Muazaroh \& Subaidi, 2019). Someone who has achieved optimal self-esteem will have a different personality from humans in general. According to Maslow in 1970 , there are several characteristics that show a person achieving self-esteem, one of which is social awareness. A person who is capable of self-esteem has a soul filled with feelings of empathy, compassion, compassion, and wants to help others. This urge will raise social awareness where he has a sense of belonging and helping others (Yuliana, 2018). 


\section{The Welfare Level of Minapadi Farmers in Epeesi Village, Basala Sub-District, South Konawe District}

Social welfare is a condition for the fulfillment of the material, spiritual and social needs of citizens in order to live properly and be able to develop themselves, so that they can carry out their social functions. The welfare level of minapadi farmers and lowland rice farmers in Epeesi village according to BKKBN can be seen in Table 6 below.

Table 6. The Welfare Level of Minapadi Farmers in Epeesi Village, Basala Sub-District, South Konawe District

\begin{tabular}{ccc}
\hline \multirow{2}{*}{ Welfare Level } & \multicolumn{2}{c}{ Mina Padi } \\
\cline { 2 - 3 } & Frequency & Percentage \\
\hline KPS & 11 & 30,56 \\
KS I & 15 & 41,67 \\
KS II & 0 & 0,00 \\
KS III & 9 & 25 \\
KS III + & 1 & 2,78 \\
\hline Total & 36 & 100,00 \\
\hline
\end{tabular}

Source: Primary data processed, 2020

Minapadi cultivation is an integrated cultivation that can increase the productivity of rice fields, that is, besides not reducing the rice yields, it can also produce fish. Paddy fields become fertile with the presence of fish manure that contains various nutrients, thereby reducing the use of fertilizers (Akbar, 2017). Economically, minapadi farming is more profitable for farmers, this is because farmers get revenue from rice production and fish production. Minapadi system has also been known as a technology that is able to make a positive contribution to rice farmers (Lantarsih, 2016). Minapadi cultivation has several advantages, among others; increase farmers' income, increase rice production, increase land efficiency and productivity, rice plants are more concerned because farmers often go to the fields so that rice plant growth is better monitored so that the yields increase (Hardiyanto, Isyanto , \& Sujaya, 2018).

The average welfare of Minapadi farmers is still low because they were in the I prosperous family category (KS I). This happens because Minapadi farmers did not fulfill the psychological needs indicators by 15 household with a percentage of $41.67 \%$ from a total of 36 households. The welfare in the KPS, KS I and KS II categories are still low and KS III and KS III + are classified as high welfare levels (Pradipta, 2017). The non-fulfillment of welfare indicators, whether indicators of basic needs, psychological needs, development needs, and self-esteem is due to the lack of income of farmers because the fulfillment of all indicators mostly uses costs. Farmers' income is one of the benchmarks in observing the level of farmer welfare, which in turn is a benchmark for agricultural development (Putri \& Noor, 2018). The welfare level is still a concern because as time goes by, the welfare of farmers decreases. Income becomes a measure of food security by looking at the purchasing power of households in accessing food. Low income is one indicator of the low economic access of farmers which can affect the level of farmer welfare (Mahmudiono \& Amalia, 2017).

\section{CONCLUSIONS AND SUGGESTIONS}

After conducting research on the welfare level of the Minapadi farmers community, conclusions can be drawn as follow. The average welfare of Minapadi farmers in Epeesi Village is low because they are in the prosperous family category I (KS I). This is because the indicators that are variable in the research are not fulfilled, namely psychological needs, development needs and selfesteem so that the majority of Minapadi farmer communities are still in the category of prosperous family stage I (KS I). The welfare level of the village community in Epeesi Village through the welfare indicators from the BKKBN cannot be used as a reference that minapadi farmers are not profitable, but the level of welfare is more emphasized on fulfilling the indicators set by the BKKBN, namely basic needs, psychological needs, developmental needs and self-esteem. Based on the research and discussion carried out, it is suggested that Minapadi farmers try to improve their welfare by fulfilling the indicators that have been set by the BKKBN. 


\section{REFERENCES}

Akbar, A. (2017). Peran Intensifikasi Mina Padi Dalam Menambah Pendapatan Petani Padi Sawah Di Gampong Gegarang Kecamatan Jagong Jeget Kabupaten Aceh Tengan. Jurnal S. Pertanian, 1(1), 28-38.

BPS. (2019). Statistik Kesejahteraan Rakyat Sulawesi Tenggara. Kendari: CV. Metro Graphia.

camelta, E. (2013). Pemanfaatan Internet Oleh Mahasiswa Jurusan Teknik Sipil Fakultas Teknik Universitas Negeri Padang. CIVED, 1(2), 142-146.

Dewi, M. A. L., \& Dewi, N. P. M. ( 2018). Pengaruh Umur, Pendidikan dan Jumlah Tanggungan Keluarga Terhadap Pendapatan Pekerja Perempuan Sektor Informal di Kota Denpasar. EJurnal EP Unud, 7(1), 1-29.

Hardiyanto, T., Isyanto , A. Y., \& Sujaya, D. H. (2018). Faktor-Faktor Yang Berpengaruh Terhadap Produktivitas Usaha Tani Mina Padi di Kota Tasik Malaya. Jurnal Pemikiran Masyarakat Ilmiah Berwawasan Agribisnis, 4(1), 25-39.

Lantarsih, R. (2016). Pengembangan "minapadi kolam dalam" di Kabupaten Sleman. Jurnal AGRARIS: Journal of Agribusiness Rural Development Research, 2(1), 17-27.

Mahendra, A. D., \& Woyanti, N. (2014). Analisis pengaruh pendidikan, upah, jenis kelamin, usia dan pengalaman kerja terhadap produktivitas tenaga kerja (Studi di Industri Kecil Tempe di Kota Semarang). Fakultas Ekonomika dan Bisnis,

Mahmudiono, T., \& Amalia, I. N. ( 2017). Hubungan Pendapatan, Total Pengeluaran, Proporsi Pengeluaran Pangan Dengan Status Ketahanan Rumah Tangga Petani Gurem (Studi di Desa Nogosari Kecamatan Rambipuji Kabupaten Jember). Amerta Nutr, 1(12), 134-152.

Masyhuri, M., \& Zainuddin, M. (2011). Metodologi Penelitian: Pendekatan Praktis dan Aplikatif (Edisi Revisi). In: Refika Aditama.

Muazaroh, S., \& Subaidi. (2019). Kebutuhan Manusia Dalam Pemikiran Abraham Maslow (Tinjauan Maqasid Syariah). Al Mazahib, 7(1), 17-33.

Ningrum, N. Z., Limi, M. A., \& Fyka, S. A. (2019). Analisis Multiplier Effect Pengembangan Sistem Mina Padi Bagi Masyarakat Lokal di Desa Epeesi Kecamatan Basala Kabupaten Konawe Selatan. Jurnal JIA : Jurnal Agribisnis dan IImu Sosial Ekonomi Pertanian, 4(6), 166-172.

Pradipta, M. (2017). Tingkat Kesejahteraan Keluarga Petani Padi di Desa Sumberagung Kecamatan Moyudan Kabupaten Sleman Daerah Istimewa Yogyakarta., Skripsi. Fakultas Ekonomi. Universitas Negeri Yogyakarta.Yogyakarta.,

Purwanto, A., \& Taftazani, B. M. (2018). Pengaruh Jumlah Tanggungan Terhadap Tingkat Kesejahteraan Ekonomi Keluarga Pekerja K3L Universitas Padjadjaran. Jurnal Focus: Jurnal Pekerjaan Sosial, 1(2), 33-43.

Putri, C. K., \& Noor, T. I. (2018). Analisis Pendapatan dan Tingkat Kesejahteraan Rumah Tangga Petani Padi Sawah Berdasarkan Luas Lahan di Desa Sindangsari, Kecamatan Banjarsari, Kabupaten Ciamis, Provinsi Jawa Barat. Jurnal IImiah Mahasiswa Agroinfo Galuh, 4(3), 927935.

Sari, D. K., Haryono, D., \& Rosanti, N. (2014). Analisis pendapatan dan tingkat kesejahteraan rumah tangga petani jagung di kecamatan natar kabupaten lampung selatan. Jurnal IImu-IImu Agribisnis, 2(1), 64-70.

Sudiharta, P. S. P., \& Sutrisna, K. (2014). Pengaruh PDRB Per Kapita, Pendidikan, dan Produktifitas Tenaga Kerja Terhadap Kemiskinan di Provinsi Bali. E-Jurnal Ekonomi Pembangunan Universitas Udayana, 3(10), 431-439.

Sularno, S., \& Jauhari, S. (2014). Peluang Usaha Melalui Agribisnis Mina padi Untuk Meningkatkan Pendapatan Petani. Jurnal SEPA: Jurnal Sosial Ekonomi Pertanian dan Agribisnis, 10(2), 268-274.

(Undang-Undang Republik Indonesia Nomor 11 Tahun 2009). Kesejahteraan Sosial.16 Januari 2009. Lembaran Negara Republik Indonesia Tahun 2009 Nomor 12.Jakarta.

Wardie, J. (2015). Analisis Pendapatan ddan Kesejahteraan Petani Padi Lokal Lahan Pasang Surut di Kapuas. Skripsi. Fakultas Pertanian. Universitas Palang karaya.Kalimantan Tengah.,

Yuliana, H. (2018). Teori Abraham Maslow dalam Analisa Kebutuhan Pemustaka. Libraria, 6(2), 349376. 